Acta vet. scand. $1986,27,267-279$.

From Centre de Recherche en Reproduction Animale, Faculté de Médicine Vétérinaire, Université de Montréal, Canada and Department of Animal Reproduction, Royal Veterinary and Agricultural University,

Copenhagen, Denmark.

\title{
MEIOSIS IN BOVINE OOCYTES MATURED IN VITRO AND IN VIVO
}

\author{
By
}

W. A. King, D. Bousquet, T. Greve and A. K. Goff

\begin{abstract}
KING, W. A., D. BOUSQUET, T. Greve and A. K. GOFF: Meiosis in bovine oocytes matured in vitro and in vivo. Acta vet. scand. 1986, 27, 267-279. - Meiosis in bovine oocytes has been studied after maturation in vitro or in vivo. Oocytes for in vitro maturation were collected from the ovaries of slaughtered cattle without regard to the phase of the estrous cycle while in vivo maturation was studied in oocytes from gonadotrophin-stimulated heifers at times varying between 6 and $36 \mathrm{~h}$ after the beginning of behavioural estrus. Oocytes from slaughtered cattle were classified according to their cumulus complex and ooplasm and were cultured for $6,12,18,24,36$ or $48 \mathrm{~h}$ in modified Krebs-Ringer bicarbonate buffer before fixation for cytogenetic analysis. Oocytes from stimulated heifers were aspirated from follicles or flushed from the oviducts, classified according to cumulus and ooplasm, and fixed within $6 \mathrm{~h}$ of collection. Nuclear maturation was more rapid in vitro than in vivo. The largest proportion of oocytes reached maturity (MII) after 12 to $18 \mathrm{~h}$ in culture or 30 to $36 \mathrm{~h}$ after the onset of behavioural estrus. Oocytes devoid of cumulus cells or showing signs of vacuolation or degeneration had virtually no capacity for nuclear maturation.
\end{abstract}

maturation; in vitrofertilization; cattle.

In vitro fertilization (IVF) of bovine oocytes has applications in both livestock production and research (Brackett 1983). In several recent studies bovine oocytes, recovered either from estrous females or from ovaries collected from slaughtered cattle without regard to their stage of the estrous cycle, were fertillized in vitro (e.g. Brackett et al. 1982, Ball et al. 1983, Greve et al. 1984, Iritani et al. 1984, Sirard et al. 1985). In terms of the number of calves born, the success of even in vivo maturation is small (Brackett et al. 1982, 1984, Sirard et al. 1986), and no calves have yet been born following IVF of in vitro maturation, but preg- 
nancies have been reported (Critser et al. 1986). Although these failures may also involve other unsuitable conditions during IVF, the resumption and completion of meiosis (nuclear maturation) and proper ooplasmic and membrane maturation are undoubtedly critical to the success of the procedure (Moor \& Warnes 1979 , Staigmiller \& Moor 1984).

Germinal vesicle breakdown and resumption of meiosis are induced by the LH surge at estrus (Tsafiri et al. 1972). The length of time required for the maturation of the nucleus (progression of meiosis from germinal vesicle stage to the second meiotic metaphase) depends on the species. In most mammals, the oocyte is ovulated at the second meiotic metaphase stage. In the cow, this occurs approximately $36 \mathrm{~h}$ after the initial rise of the LH surge or the onset of estrus (Bernard et al. 1983) or $22 \mathrm{~h}$ after the LH peak (Yadav et al. 1985, Callesen et al. 1984 and 1986). Removal of oocytes from follicles and maintaining them under suitable culture conditions is sufficient to induce the resumption of meiosis and maturation of the nucleus (Pincus \& Enzmann 1935). The time interval required for this maturation in vitro also varies according to species and, in the cow, has been reported to be $24 \mathrm{~h}$ or more after removal from the follicle (Sreenan 1970, Jagiello et al. 1974, Shea et al. 1976).

An effect of maturity of the nucleus (stage of meiosis) on IVF rate in laboratory animals has been demonstrated (Chang 1955 ). In the cow the proportion of oocytes that are fertilized and cleave normally is substantially increased as the oocytes approach the second meiotic metaphase at the time of co-culture with semen (Greve et al. 1984). Further, fertilization in vitro or in vivo of aged, as well as immature, oocytes leads to abnormal development of the zygote, at least in women (Trounson et al. 1982). For successful IVF it is therefore important to begin the co-culture of the oocytes and sperm when the oocytes are mature but not aged.

In order to obtain comparative information about the stages of nuclear maturation in vitro and in vivo as well as the time intervals involved, oocytes were fixed for chromosome analysis at various times after collection from ovaries of slaughtered cattle (in vitro maturation) or after surgical collection at various time intervals after the onset of estrus in superovulated females (in vivo maturation). With the hope of identifying physical parameters which might be useful for selection of oocytes for 
IVF studies, morphological features such as appearance of cumulus mass and ooplasm were taken into consideration along with the stage of nuclear maturation.

\section{MATERIALS AND METHODS}

\section{In vitro maturation}

Ovaries were collected from 92 heifers and cows, mostly Canadian Holstein breed, at a slaughter-house and were maintained at room temperature. The follicular fluid was aspirated into $5 \mathrm{ml}$ syringes fitted with 20 gauge needles and contained either $1 \mathrm{ml}$ warm $\left(37^{\circ} \mathrm{C}\right)$ modified Krebs Ringer bicarbonate buffer medium (KRB) (Fukui et al. 1982) supplemented with heparin (50 i.u./ml) or cold $\left(4^{\circ} \mathrm{C}\right)$ phosphate-buffered saline (PBS) solution with heparin. Large follicles $(>5 \mathrm{~mm})$ were aspirated individually but, in the case of small follicles $(<5 \mathrm{~mm})$, several were aspirated into the same syringe. Aspiration of the follicles and initiation of culture was completed within $45 \mathrm{~min}$ of slaughter. The KRB syringes were then maintained at $30^{\circ}-$ $37^{\circ} \mathrm{C}$ while transported to the laboratory, whereas samples not destined for culture (controls) were aspirated into syringes containing cold PBS and packed on ice for transport. The contents of the syringes were transferred to Petri dishes, and oocytes, located by means of a stereomicroscope, were transferred individually to fresh KRB in multi-well culture dishes containing 1 $\mathrm{ml}$ of medium without heparin or to cold $\left(4^{\circ} \mathrm{C}\right)$ PBS. The oocyte classification was essentially as described by Leibfried \& First (1979). Thus they were graded first as to the appearance of the cumulus cells: Type 1, corona and several additional layers of tight cumulus cells; Type 2, a corona of two to three layers of cumulus cells; Type 3 , incomplete corona and cumulus cell layers; Type 4, nude oocytes. Activated cumulus (expanded/dissociated) were classified as Type 5 and Type 6 . When possible, oocytes were further classified according to the ooplasm: Type 1, even granulation; Type 2, granulated, Type 3, vacuolated. Degenerated ooplasma was classified as Type 4. All oocytes, except for controls, were cultured for $6,12,18,24,30,36$ or $48 \mathrm{~h}$ at $37^{\circ} \mathrm{C}$ under $5 \% \mathrm{CO}_{2}$ in air with $100 \%$ humidity. At the end of the culture period, individual oocytes which were surrounded by cumulus were treated briefly $(1-5 \mathrm{~min})$ with a trypsin $(0.25 \%)$ - EDTA $(0.02 \%)$ solution until they were denuded. These de- 
nuded oocytes were treated with hypotonic tri-sodium citrate ( $0.88 \%$ solution for 3 to 5 min, then transferred onto a microscope slide and fixed in methanol : acetic acid (1:1 followed by 3:1) (King et al. 1979). Slides were subsequently air-dried and stained with Giemsa or aceto-orcein. The stage of nuclear maturation was determined as intact germinal vesicle (GV), germinal vesicle breakdown (early to late diakinesis, GVB), first metaphase (MI) or second metaphase (MII).

\section{In vivo maturation}

Oocytes were collected from 12 superovulated Canadian Holstein heifers at slaughter $(n=2)$ or surgery $(n=10)$. The detailed description of the protocol is presented in detail elsewhere (Greve et al. 1984). Briefly, oocytes were aspirated from follicles into syringes, as above, 6 to $36 \mathrm{~h}$ after the beginning of estrus or were flushed from the oviduct $(36 \mathrm{~h})$. Oocytes were isolated, classified, cultured ( 1 to $6 \mathrm{~h}$ ), fixed and stained as above.

\section{RESULTS}

The progression of the stages of meiosis from GV to MII are shown in Figs. 1 to 5, which are representative of the material matured both in vivo and in vitro. With the exception of two diploid MII spreads (Fig. 6) in the in vitro matured group, MI and MII were characterized by 30 or less bivalents and univalents, respectively. The hypohaploid metaphases were attributed to chromosome loss due to mechanical disruption of the metaphase since no hyperhaploid metaphases (31 or more bivalents or univalents) were observed. Otherwise, the features of these stages did not differ from those of most mammalian species (Donahue 1968, McGaughey \& Chang 1969, Jagiello et al. 1974).

\section{In vitro}

A total of 220 oocytes was collected from the ovaries of 92 females. The results of microscopic analysis following fixation of the oocytes are summarized in Fig. 7. Of the 173 oocytes cultured for $6 \mathrm{~h}$ or more, $63(36.4 \%)$ resumed meiosis (GVB) or completed the division to MII. The percentage of degenerate oocytes (i.e., those in which no recognizable stages of meiosis could be identified) increased from $20 \%$ at time zero to $80 \%$ after $48 \mathrm{~h}$ culture. However, a portion (3.4\%-18.2\%) remain- 
T a b l e 1. Classification * of cumulus, ooplasm and nuclear maturation of ovarian bovine oocytes cultured for $12 \mathrm{~h}$ or longer.

\begin{tabular}{|c|c|c|c|c|c|c|}
\hline & \multicolumn{6}{|c|}{ Cumulus classification } \\
\hline & 1 & 2 & 3 & 4 & 5 & 6 \\
\hline \multirow{4}{*}{$\begin{array}{l}\text { Number } \\
\text { Complete nuclear } \\
\text { maturation }(\%)\end{array}$} & 42 & 27 & 31 & 35 & 13 & 3 \\
\hline & $7(16.7)$ & $6(22.2)$ & $9(29.0)$ & $1(29.0)$ & $1(7.7)$ & $1(33.3)$ \\
\hline & \multicolumn{4}{|c|}{ Ooplasm classification } & & \\
\hline & 1 & 2 & 3 & 4 & & \\
\hline Number & 67 & 67 & 25 & 6 & & \\
\hline $\begin{array}{l}\text { Complete nuclear } \\
\text { maturation }(\%)\end{array}$ & $14(20.8)$ & $7(10.4)$ & $9(4)$ & $0(0)$ & & \\
\hline
\end{tabular}

* See text for details of the classification.

ed at the germinal vesicle stage throughout the culture period. The highest percentage of GVB/MI (41.1 and $40.5 \%$ ) occurred at $6 \mathrm{~h}$ and $12 \mathrm{~h}$ while MII $(27.6 \%)$ was most frequent at $18 \mathrm{~h}$.

The cumulus classification for 151 cumulus-oocyte complexes and ooplasmic classifications for $\mathbf{1 6 5}$ oocytes are summarized in Table 1. Complete nuclear maturation was least likely to occur in nude (Type 4) oocytes or in those with vacuolated Type 3) or degenerate (Type 4) ooplasm. The potential for nuclear maturation was not affected by antral follicular size.

In vivo

Of the 196 oocytes collected from the 12 donors (Greve et al. 1984), 51 were selected as representative controls and fixed. The stage of nuclear maturation at various time intervals following the onset of estrus are summarized in Fig. 8. The largest portion $(35.3 \%)$ were observed at MII in the group collected 30 to $36 \mathrm{~h}$ after the onset of behavioural estrus. The earliest time at which tubal oocytes were obtained was $26 \mathrm{~h}$ after the beginning of estrus. A total of 40 tubal oocytes were collected of which 32 (80\%) had no cumulus cells, 2 (5\%) had Type 2 cumulus, 4 (10\%) Type 3, and 2 (5\%) Type 5 (Greve et al. 1984). These oocytes were used for in vitro fertilization and a cytogenetic analysis not attempted. In the cows from which tubal oocytes were collected, 18 follicular oocytes were also aspirated. Of these follicular oocytes, 7 (39\%) had activated (Type 5) cumulus. 
From the same group of animals the ooplasm was classified as Type 1 in $10(55.5 \%)$ and $37(92.5 \%)$, Type 2 in $5(27.7 \%)$ and $3(7.5 \%)$ and Type 3 or 4 in $3(16.6 \%)$ and 0 of follicular and tubal oocytes, respectively.

\section{DISCUSSION}

The time in culture required for breakdown of the germinal vesicle and resumption of meiosis to first metaphase (6 to $18 \mathrm{~h}$ ) and second metaphase (12 to $24 \mathrm{~h}$ ) for oocytes matured in vitro under the conditions described here, generally corresponds with that reported by others in the cow (Sreenan 1970, Jagiello et al. 1974, Trounson et al. 1977, Motlik et al. 1978). However, MII configurations were first observed after only $12 \mathrm{~h}$ culture with the percentage at MII reaching a maximum at 18 to $24 \mathrm{~h}$, which was earlier than observed by others (Sreenan 1970, Shea et al. 1976). This earlier detection of MII may be due to the use of more accurate methods for determining nuclear maturation, which are based on chromosome morphology and do not rely on the appearance of the first polar body.

The percentage of oocytes which had already resumed meiosis $(28.9 \%)$ or completed meiosis $(2.2 \%)$ in the control group was also higher than previously reported (Jagiello et al. 1974). This may be due to aspiration of oocytes from follicles after the LH surge or from atretic follicles in our study. Certain oocytes presumably originated from preovulatory or atretic follicles but no distinction was made regarding the condition of the follicles at the time of aspiration. Since culture of bovine oocytes at $30^{\circ} \mathrm{C}$ rather than 35 to $37^{\circ} \mathrm{C}$ reduces the rate of maturation significantly (Katska \& Smorag 1985), it is felt that refrigeration from the time of collection until fixation ( 2 to 4 ) would restrict maturation. In that follicles were randomly selected to represent the total population of oocytes, it is considered that they do indeed represent the oocyte population at the time of removal. The percentage of degenerated oocytes rose from $21 \%$ to $80 \%$ after $48 \mathrm{~h}$ of culture suggestive, perhaps, of the inability of the medium to maintain the oocytes for long periods of culture.

In comparison, the rate of maturation in vivo after the onset of estrus was slower, with the first observation of the second metaphase at $18 \mathrm{~h}$ after the onset of estrus but with the greatest percentage occurring 30 to $36 \mathrm{~h}$ after estrus. Since laparoscopic 
W. A. King, D. Bousquet, T. Greve and A. K. Goff: Meiosis in bovine oocytes matured in vitro and in vivo.

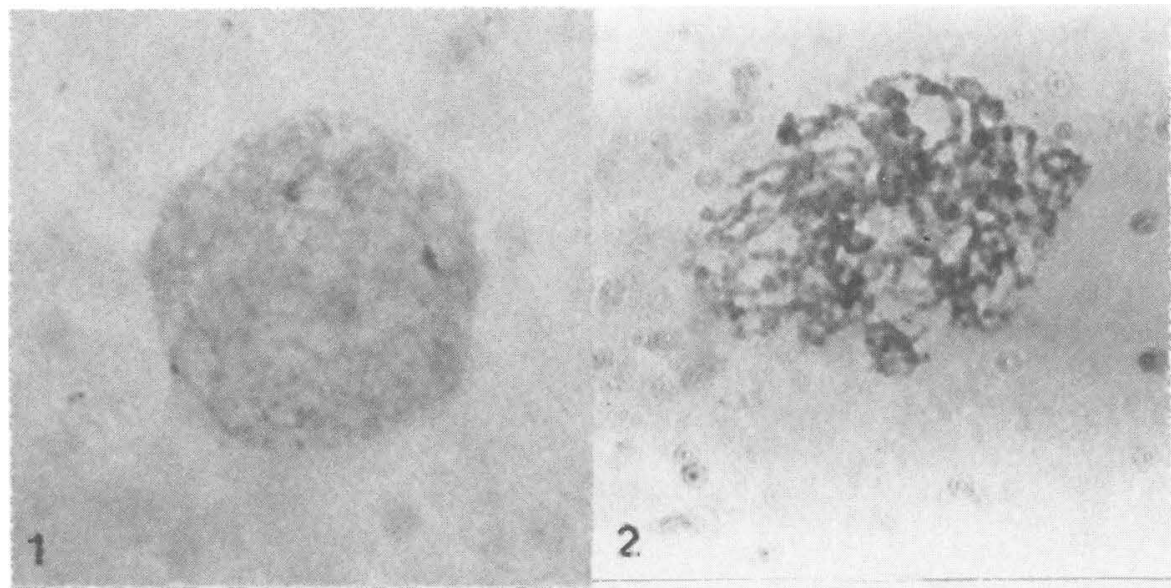

3
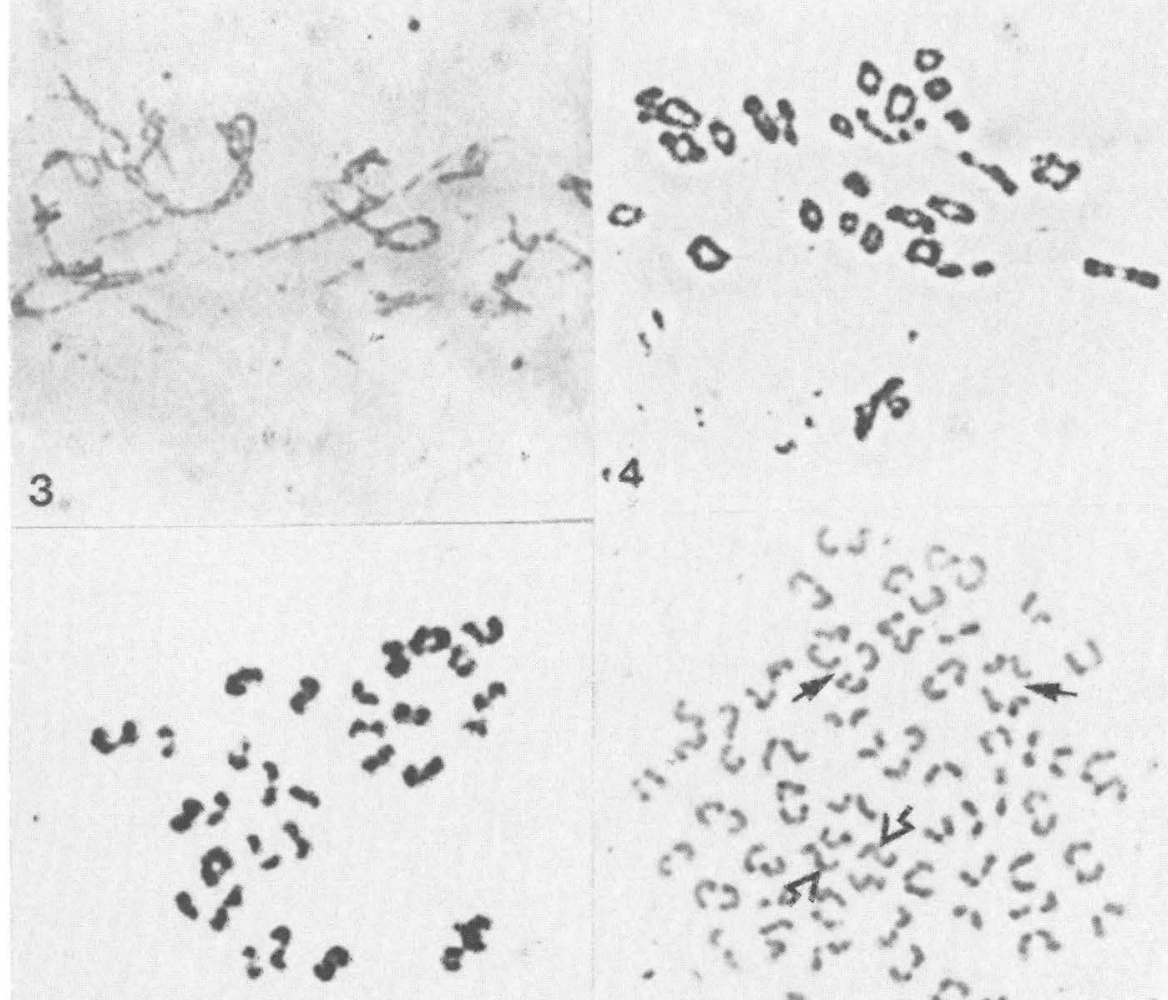

5

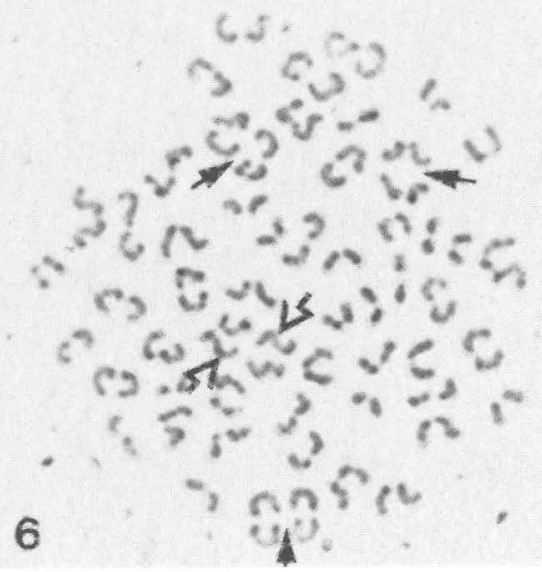

Figure 1-6. Representative stages of meiosis in bovine oocytes collected from slaughtered cattle and cultured in vitro. (1) Intact germinal vesicle; (2) germinal vesicle breakdown, diplotene; (3) late diplotene; (4) diakinesis-metaphase I; (5) metaphase II; (6) diploid metaphase II, note the endto-end association of the $X$ chromosomes (open arrows) and several pairs of autosomes (solid arrows). 



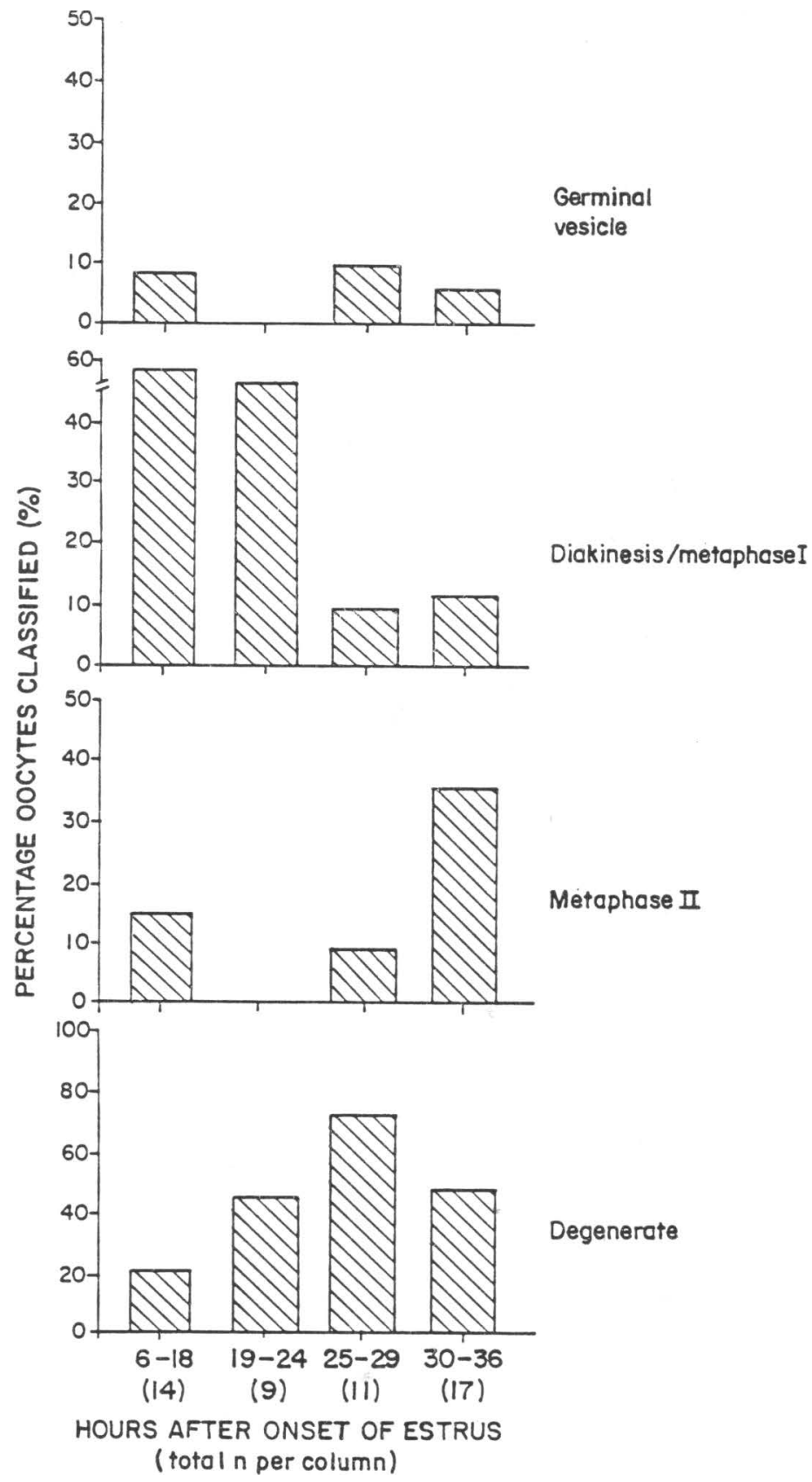

Figure 7. Results of microscopic analysis of the 220 fixed and stained in vitro matured cattle oocytes following various culture periods $(0-48 \mathrm{~h})$. 


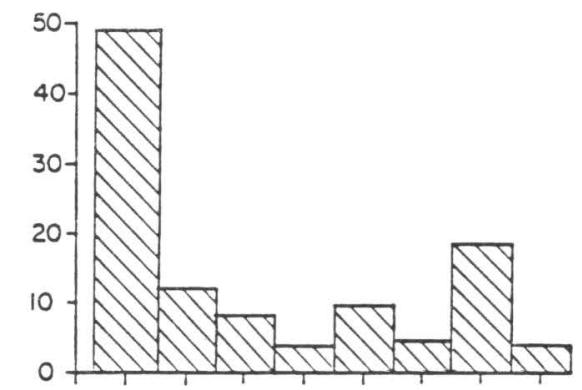

Germinal

vesicle

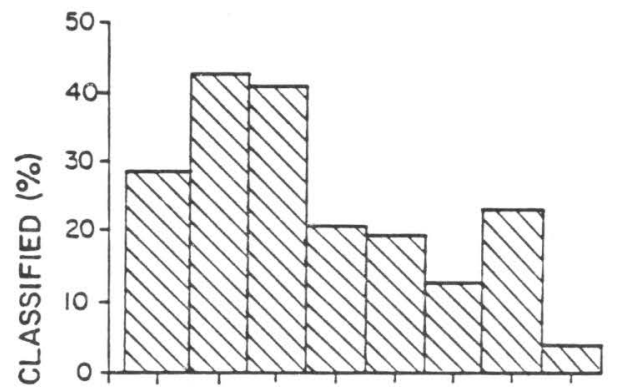

Diakinesis/metaphase I

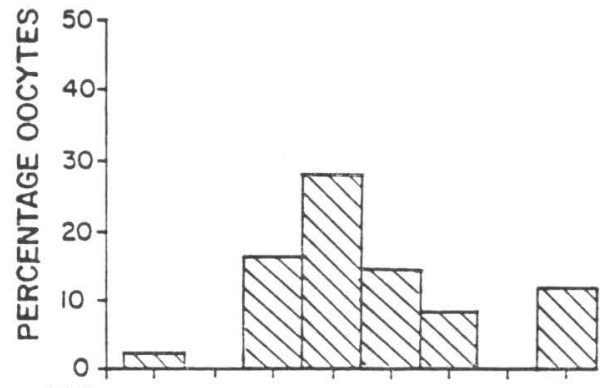

Metaphase II

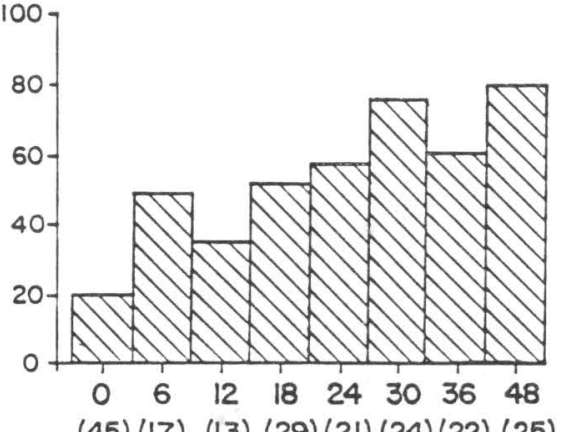

(45) (17) (13) (29) (21) (24)(22) (25)

HOURS OF CULTURE

(total n per column)

F igu re 8. Results of microscopic analysis of the 51 fixed and stained in vivo matured bovine follicular oocytes recovered at various intervals after the onset of estrus. 
collection of in vivo matured oocytes is usually based on behavioural estrus (Sirard et al. 1985), this timing has practical importance. Others have reported that cow oocytes reach the second meiotic metaphase $19-25 \mathrm{~h}$ after the LH peak (Trounson et al. 1977, Kruip et al. 1983).

The combined percentage of degenerated oocytes collected $6-36 \mathrm{~h}$ after the onset of estrus from superovulated heifers $(45.1 \%)$ was generally higher than that of those collected from the slaughtered unstimulated group and fixed without culture (21\%). In a parallel study (Greve et al. 1984) using oocytes from the same stimulated donors collected at the same time, a similar high portion of degenerated unfertilized oocytes $(46.7 \%)$ was observed after IVF treatment. These oocytes may have originated from follicles destined to become atretic as has been suggested by Moor et al. (1984). If they were destined to have been ovulated and fertilized, they might be a source of poor quality embryos as indicated by Callesen et al. (1984 and 1986). However, it should be noted that two of the donor heifers in the study (Greve et al. 1984) did not show full signs of behavioural estrus (standing to be mounted) and these two contributed to the high proportion of degenerated oocytes.

With the exception of hypohaploid metaphases rising from mechanical loss of chromosomes, and two diploid MII configurations resulting from the failure to extrude the first polar body, no chromosome abnormalities were found. Jagiello et al. (1974) reported a similar lack of abnormalities (two diploid MII out of 102 analysed) while Farver Koenig et al. (1983) reported $23.1 \%$ abnormalities including hyperploidy, structural abnormalities, the presence of mitotic chromosomes, multiple polar bodies or binucleation. The lack of structural chromosome abnormalities observed in this study may reflect the fact that the origin of the material was primarily of the Holstein breed which is known for its lack of chromosome abnormalities.

In previous in vitro maturation studies of bovine oocytes only Type 1 cumulus oocyte complexes have been used (e.g. Motlik et al. 1978, Süss \& Wüthrich 1985). The present study indicates that oocytes with Types 2, 3 and 5 cumulus had an almost identical meiotic competence. Follicular size had no effect on the potential for nuclear maturation. The evaluation of ooplasma also proved a useful parameter of meiotic competence. Oocytes with overt signs of vacuolization or degeneration had virtually 
no capability of nuclear maturation. These observations are in agreement with previous studies (Liebfried \& First 1979, Fukui \& Sakuma 1980). Meiotic competence and developmental potential are not necessarily equivalent and need to be assessed together in order to make efficient use of oocytes collected from slaughtered animals.

\section{CONCLUSION}

The present study indicated that in vitro and in vivo maturation of bovine oocytes are not synchronous. In vitro culture hastened nuclear maturation which should be taken into consideration when attempting in vitro fertilization of follicular oocytes. The data also revealed that a high percentage of oocytes recovered from slaughter-house material and from superovulated ovaries were degenerate and could never be expected to develop into normal embryos. This would seem to limit the number of fertilizable ova that can be recovered from superovulated donors. It was also apparent that the state of the cumulus cells and the cytoplasm can be used as a means of selecting oocytes with potential for in vitro nuclear maturation.

\section{ACKNOWLEDGEMENTS}

The authors are grateful to Dr. K. J. Betteridge for valuable discussions, Mr. R. Bériault, Ms. G. Pineault and Mr. M. Desjardins for technical assistance and to Ms. H. Boucher for typing the manuscript. This project was funded by the Canadian Association of Animal Breeders and the Carlsberg Foundation (Denmark) and the Natural Sciences and Engineering Research Council of Canada.

\section{REFERENCES}

Ball, G. G., M. L. Leibfried, B. D. Bavister \& N. L. First: Factors affecting successful in vitro fertilization of bovine follicular oocytes. Biol. Reprod. 1983, 28, 717-725.

Bernard, C., J. P. Valet, R. Béland \& R. D. Lambert: Prediction of bovine ovulation by a rapid radioimmunoassay for plasma $L H$. J. Reprod. Fert. 1983, 68, 425-430.

Brackett, B. G.: A review of bovine fertilization in vitro. Theriogenology 1983, 19, 1-15.

Brackett, B. G., C. L. Keefer, C. G. Troop, W. J. Donawick \& K. A. Bennett: Bovine twins resulting from in vitro fertilization. Theriogenology 1984, 23, 224.

Brackett, B. G., D. Bosquet, M. L. Boice, W. J. Donawick, J. F. Evans \& M. A. Dressel: Normal development following in vitro fertilization in the cow. Biol. Reprod. 1982, 27, 147-158. 
Callesen, H., T. Greve \& P. Hyttel: Preovulatory endocrinology and oocyte maturation in superovulated cattle. Theriogenology 1986, $25,71-86$.

Callesen, H., T. Greve \& P. Hyttel: Follicular steroids and ovarian development in superovulated dairy cattle. A preliminary report. J. In Vitro Fert. Embryo Transf. 1984, 1, 101.

Chang, M. C.: Fertilization and normal development of follicular oocytes in the rabbit. Science $1955,121,867-869$.

Critser, E. S., M. L. Leibfried-Rutledge, W. H. Evestone, D. L. Northey \& N. L. First: Acquisition of developmental competence during maturation in vivo. Theriogenology 1986, 25, 150 .

Donahue, R.: Maturation of the mouse oocyte in vitro. I. Sequence and timing of nuclear progression. J. exp. Zool. 1968, 169, 237-250.

Farver Koenig, J. L., F. E. Eldridge \& N. Harris: A cytogenetic analysis of bovine oocytes cultured in vitro. J. Dairy Sci. 66 (Suppl. 1) 1983, 253. (Abstr.).

Fukui, Y.\& Y. Sakuma: Maturation of bovine oocytes cultured in vitro: Relation to ovarian activity, follicular size and the presence or absence of cumulus cells. Biol. Reprod. 1980, 22, 669-673.

Fukui, Y., M. Fukushima, Y. Terawak \& H. Ono: Effects of gonadotropins, steroids and culture media on bovine oocyte maturation in vitro. Theriogenology 1982, 18, 161-175.

Greve, T., D. Bousquet, W. A. King \& K. J. Betteridge: In vitro fertilization and cleavage of in vivo matured bovine oocytes. Theriogenology $1984,22,151-165$.

Iritani, A., M. Kasai, K. Niwa \& H. B. Song: Fertilization in vitro of cattle follicular oocytes with ejaculated spermatozoa capacitated in a chemically defined medium. J. Reprod. Fert. 1984, 70, $487-492$.

Jagiello, G. M., W. A. Miller, M. B. Ducayen \& J. S. Lin: Chiasma frequency and disjunctional behaviour of ewe and cow oocytes matured in vitro. Biol. Reprod. 1974, 10, 354-363.

King, W. A., T. Linares, I. Gustavsson \& A. Bane: A method for preparation of chromosomes from bovine zygotes and blastocysts. Vet. Sci. Commun. 1979, 3, 51-56.

Leibfried, L. \& N. L. First: Characterization of bovine follicular oocytes and their ability to mature in vitro. J. Anim. Sci. 1979, 48, 7686.

McGaughey, R. W. \& M. C. Chang: Meiosis of mouse eggs before and after sperm penetration. J. exp. Zool. 1968, 170, 397-410.

Moor, R. M., Th. A. M. Kruip \& D. Greed: Intraovarian control of folliculogenesis: limits to superovulation. Theriogenology 1984, $21,103-116$.

Moor, R. M. \& G. M. Warnes: Regulation of meiosis in mammalian oocytes. Brit. med. Bull. 1979, 35, 99-103.

Motlik, J., H. H. Koefoed-Johnsen \& J.Fulka: Breakdown of the germinal vesicle in bovine oocytes cultured in vitro. J. exp. Zool. 1978, $205,377-384$. 
Pincus, G. \& E. V. Enzmann: The comparative behaviour of mammalian eggs in vitro and in vivo. I. The activation of ovarian eggs. J. exp. Med. 1935, 62, 665-675.

Shea, B. F., J. P. A. Latour, K. N. Bedirian \& R. D. Baker: Maturation in vitro and subsequent penetrability of bovine follicular oocytes. J. Anim. Sci. 1976, 45, 809-815.

Sirard, M. A., R. Lambert \& R. Béland: Evaluation of bovine capacitation by in vitro fertilization. Theriogenology 1984, 21, 261 (Abstr.).

Sirard, M. A., R. D. Lambert, P. Guay, D. P. Menard \& M. Bedoya: In vivo and in vitro development of in vitro fertilized bovine follicular oocytes obtained by laparoscopy. Theriogenology 1985, 23, 230 (Abstr.).

Sirard, M. A., R. D. Lambert, D. P. Menard \& M. Bedoya: In vitro fertilization in the cow: 6 calves are born from surgical or nonsurgical uterine transfer to heifers. Theriogenology 1986, 25, 198.

Sreenan, J.: In vitro maturation and attempted fertilization of cattle follicular oocytes. J. Agric. Sci., Camb. 1970, 75, 393-396.

Staigmiller, R. B. \& R. M. Moor: Effect of follicle cells on the maturation and development competence of bovine oocytes matured outside the folllicle. Gamete Research 1984, 9, 221-229.

Süss, U. \& K. Wüthrich: Stages of the first meiotic division observed in bovine oocytes matured in vitro. Theriogenology 1985, 23, 231 (Abstr.).

Trounson, A. O., S. M. Willadsen \& L. E. A. Rouson: Fentilization and development capability of bovine follicular oocytes matured in vitro and in vivo and transferred to the oviducts of rabbits and cows. J. Reprod. Fert. 1977, 51, 321-327.

Trounson, A. O., L. R. Mohr, C. Wood \& J. F. Leeton: Effect of delayed insemination on in vitro fertilization, culture and transfer of human embryos. J. Reprod. Fert. 1982, 64, 285-294.

Tsafriri, A., H. R. Lindner, U. Zur \& S. A. Lamprecht: In vitro induction of meiotic division in follicle-inclosed rat oocytes by $\mathrm{LH}$, cyclic AMP and prostaglandin $\mathrm{E}_{2}$. J. Reprod. Fert. 1972, 31, $39-50$.

Yadav, M. C., K. E. Leslie \& J. S. Walton: The onset and duration of ovulation in superovulated beef heifers. Theriogenology 1985, 23, 237. (Abstr.)

\section{SAMMENDRAG}

In vitro og in vivo modning af bovine oocyter.

Meiosens tidsmæssige forl $\varnothing b$ og strukturelle forhold blev sammenlignet ved in vitro og in vivo modning.

Til in vitro studierne indsamledes cumulus-oocyt-komplekser (COC) fra slagtehusmateriale. Efter vurdering af cumuluscellelagene og ooplasma blev en del straks lagt på is (kontroloocyter), mens de $\phi \mathrm{v}-$ rige blev dyrket $\mathrm{i}$ Krebs-Ringer bikarbonatopl $\varnothing$ sning $\mathrm{i}$ henholdsvis 6 , 
12, 18, 24, 36 og 48 timer. Efter endt dyrkningsperiode blev cumuluscellelagene fjernet og oocyten fikseret og farvet med henblik på en cytogenetisk vurdering. In vivo modnede oocyter blev aspireret fra ovarier eller udskyllet af ovidukter på superovulerede køer 6-36 timer efter stående brunsts begyndelse. Deres cumuluscellelag og ooplasma blev vurderet straks efter opsamling og 6 timer senere blev de fikseret, farvet og underkastet en cytogenetisk vurdering.

Resultaterne viste, at meiosen forl $\varnothing$ ber hurtigere in vitro end in vivo, at hovedparten af de in vitro dyrkede oocyter afslutter deres modning, d. v.s. har nået MII-stadiet efter 12-18 timer, at hovedparten af de in vivo modnede findes på MII-stadiet $30-36$ timer efter brunstens begyndelse og endelig, at oocyter uden cumuluscellelag og/ eller tegn på degeneration ikke besidder evnen til at gennemføre en normal meiose. Det blev endvidere godtgjort, at oocyter, der kommer fra dyr med afvigende hormonprofiler, har en ringere kvalitet målt ved deres modningsevne.

(Received February 25, 1986).

Reprints may be requested from: W. A. King, C.R.R.A., Faculté de Médecine Vétérinaire, Université de Montréal, C.P. 5000, St.-Hyacinthe, Québec, Canada J2S 7C6. 